DOI: https://doi.org/10.24127/ajpm.v9i2.2687

\title{
SECONDARY SCHOOL STUDENTS' ERROR OF TERM OF ALGEBRAIC FORMS BASED ON MATHEMATICAL COMMUNICATION
}

\author{
Yus Mochamad Cholily ${ }^{1 *}$, Tika Rifky Kamil ${ }^{2}$, Putri Ayu Kusgiarohmah ${ }^{3}$ \\ ${ }^{1,2}$ Magister Pendidikan Matematika, Universitas Muhammadiyah Malang, Indonesia \\ ${ }^{3}$ Magister Pendidikan Matematika, Universitas Negeri Malang, Indonesia \\ Corresponding author. Jl. Tirtomulyo VI/5, 65151, Landungsari, Malang, Indonesia \\ E-mail: $\quad y u s @ u m m . a c . i d{ }^{1 *)}$ \\ tika_406027@webmail.umm.ac.id ${ }^{2)}$ \\ ayuputrikusgiarohmah@gmail.com ${ }^{3)}$
}

Received 15 February 2020; Received in revised form 21 June 2020; Accepted 28 June 2020

\begin{abstract}
The purpose of this study is to describe students' error on (1) the ability to understand the term of algebraic forms, and (2) the ability to communicate the term of algebraic forms into words and verbal forms. This is a case study by selecting one student as a research subject. The data collected is supported by observation of learning activities in class and direct interviews with research subjects. Then the data were analyzed descriptively qualitatively to see students' understanding of similar tribes and non-similar tribes. The study shows that: (1) the ability to understand the term of algebraic forms are low because of misunderstanding the slight differences between exponent and algebra itself, and (2) the ability to communicate the term of algebraic forms into words and verbal forms are challenging for them especially when they do not really understand the concepts. This case study concludes that the students' error was the conceptual error in determining and solving of terms of algebraic forms.
\end{abstract}

Keywords: algebraic forms, mathematical communication, students' error, term.

\section{INTRODUCTION}

Algebra is a major component of mathematics around the world (Leung et al., 2014). The subject continues to be the focus of reform efforts that require a reconceptualization in school mathematics (Pepin et al., 2014). It is concerned with letter symbols, operations, and how to find the value of an unknown (Andriani, 2015) and it's more than moving symbols around (NCTM, 2000). A combination of letter, number, and figure bring a lot of confusion to the students (Julius et al., 2018).

Students begin to study algebra in more abstract and symbolic ways, focusing on understanding and using variables, expressions, and equations in middle school (Van de Walle et al.,
2016). They say that math is difficult to understand, especially for the topic of algebra (Disasmitowati \& Utami, 2017). One of the matters is having problems with algebraic notation (Ncube, 2016) with the letters changing values or other letter replacing another letter (Julius et al., 2018). The other problem is how to associate real problems into existing symbols that makes algebra seems to have many obstacles (Agasi et al., 2017).

The reasons why communicating is important in mathematics learning are it is not only a tool to aid thinking but also as social activity (Baroody \& Coslick, 1993). As social activity in mathematics learning, the process of communication occurs (Trisnawati et al., 2018). But, the students still cannot understand yet 
communicate the problem both orally or in writing (Paridjo \& Waluya, 2017). It is challenging to confirming how students express their thinking (orally or writing) that allows them to create their own mathematical meaning (Wilson, 2009). Therefore, when the process of learning mathematics takes place, students need to be given a problem to be solved orally and in writing. Through giving these problems, the teacher can identify students' mistakes to examine students' mathematical thinking.

The process of identifying and reviewing students' error has been shown to be an effective method to decide what the students' specifics needs (Brown et al., 2016). Errors identification is needed to do because all of the information re lated could be using as evaluation and developing a better quality of the mathematical learning process (Munawaroh et al., 2018).

This study refers to Molina et al., (2017) who conducted research on "Secondary School Students' Errors in the Translation of Algebraic Statements". The results of his research show that students when solving algebra inequality problems still make many mistakes when translating verbal forms into symbolic representation systems. In addition there is also a study from Daud \& Ayub, (2019) which examines the "Student Error Analysis in Learning Algebraic Expression: A Study in Putrajaya Schoolendendory School". The results of his research show that students still frequently make mistakes in the process of solving algebraic problems. That is because students do not understand the terms in algebra. Students are also less thorough in operating different variables found in algebra problems. Both studies are still focused on algebraic statements in general. Therefore, this research will focus on something more specific, namely students' understanding of terms contained in algebra.

This study focuses mainly on the following components of algebraic competence: (a) the ability to understand the term of algebraic forms; and (b) the ability to communicating the term of algebraic forms into words and verbal forms. The main topic discussed will be the students' error in studying the term algebraic forms.

\section{RESEARCH METHOD}

In this study, we analyze the tasks and problems on the topic of term algebraic forms in $7^{\text {th }}$ grade (students aged 13-14) by using the research method of the case study. The researcher observes learning between the teacher and students in one class. Next, the researcher gave a test to one randomly selected student and conducted an interview with the student. So the instruments used in this study are observation guidelines, interview guidelines, test sheet, and tape recorder.

The study begins with determining the focus of study which is algebra teaching in a class. Second, data collecting within the observation of the algebra learning process and interviewing the students. Third, the data analysis is done descriptively qualitatively based on the data that has been collected. Then, do a comparison and discussion by studying previous studies. Then, we write down our interpretations and integrate them into the report form. This study is reported an hour of the learning process in a class. In the following text, the teacher is referred to as $\mathrm{T}$ and the student is referred to as $\mathrm{S}$. 
DOI: https://doi.org/10.24127/ajpm.v9i2.2687

\section{RESULT AND DISCUSSION}

\section{The Ability To Understand The Term of Algebraic Forms}

Transformational activity is one of three core activities of conceptualizing algebra that include collecting, like terms, factoring, adding and multiplying polynomial expressions, etc. (Strømskag, 2016). From the interview, we knew that one of the students' difficulties is on algebraic forms. They confused between the similarity concept of exponential forms and algebraic forms or how to differentiate what variable is.

Exponents are used in algebraic expressions and add to the operations (Van de Walle et al., 2016). For example, when $\mathrm{S}$ asked how many terms that own $y^{2}$ variable on $3 x^{3} y^{2}+$ $12 y^{2}+6 x^{2} y^{3}-y^{2}-5-4 x^{3}+9 x^{3}$. She said that it was three of them, $3 x^{3} y^{2}, 12 y^{2}$, and $-y^{2}$. She still not understand yet that $12 y^{2}$ and $-y^{2}$ has the like term which is $y^{2}$.

The following example from the question illustrates how S's understanding of algebraic term problems that she wrote it.

1. $9 x$ has one algebraic term.

2. $3 x^{2}+6 y+2$ has three algebraic terms.

3. $2 s^{2}+3 a+4 a^{3}+5 t^{4}-7$ has four algebraic terms.

That example shows that whether S forgot the answers to the two questions above or she only writes that the algebraic term is four. She already knows that $9 x$ has one of the algebraic terms and so on. Generally, for several reasons, the students' difficulty in learning math typically lacks important conceptual knowledge so that they cannot solve certain problems consistently (Lai, 2012).
Students are hard to differentiate like terms of algebraic forms or different terms of the algebraic forms. The following is a conversation between the researcher and 2 students. The researcher referred to as $\mathrm{R}$.

$\mathrm{R}$ : "How if $p+p$ ? Is that could be plus?"

Student 1 : "Yes. That would be $2 p$." Student 2 : "No. It's $p p$."

R : "So, why did you said that? Why 'Yes'? Why 'No'?"

Student 1 : "Because they had like terms of the algebraic form."

Student 2 : "No. Because it has two $p$. So, that is $p p . "$

$\mathrm{R} \quad$ : "The right answer is 'yes'. They had like terms of the algebraic form. Look when we had one apple and another one of apple. How many apples we had now? Two apples, right? Now, refer an apple to as $a$. Then, we had $2 a$ as we know that the apples are two. $a$ is a term. When we had the same term of algebraic form, they could be plus."

\section{The Ability To Communicate The Term of Algebraic Forms Into Words and Verbal Forms}

Standard of communication are to (1) organize and consolidate mathematical thinking; (2) communicate mathematical thinking coherently and clearly to others; (3) analyze and evaluate the mathematical thinking and strategies of others; and (4) use the mathematics language to express mathematical ideas precisely (NCTM, 2000). And according to 
process standard, we can develop communication ability by inviting students to talk about, write about, describe, and explain their mathematical ideas as a way to examine their thinking.

The following conversation is about problems are another case on operations of the term of algebraic forms, when the teacher asks his students some questions.

$$
\begin{aligned}
& \text { T : " } 2 b+3 a=\cdots \text {. How do } \\
& \text { you answer?" } \\
& \text { Students : " } 5 b a, 5 b a b a, 5 b b a a \text {, } \\
& \text { 5bbaabb." } \\
& \mathrm{T} \quad \text { : "The right answer is the } \\
& \text { problem itself." } \\
& \text { Students : "Why?" } \\
& \mathrm{T} \text { : "Let's move on to the }
\end{aligned}
$$

Student 1 : "Because they had like terms of the algebraic form so we could operate that."

What we could take from this conversation is there are many students who could not know how to differentiate yet operate like terms of algebraic forms or different terms of algebraic forms yet. Although one can add or subtract "like terms," one should not attempt to simplify the addition or subtraction of "unlike terms" (Kanbir et al., 2018). Hence, $8 x+5 x=13 x$, but $8 x+5$ cannot be further simplified. And, one should not say that $8 x+4 x^{2}$ always equals $12 x^{2}$.

For a little time in the classroom, this following is a conversation between $\mathrm{R}$ and $\mathrm{S}$.

$$
\begin{aligned}
& \mathrm{R} \quad \text { : "So, what if } 3 b-2 a \text { ? What is } \\
& \mathrm{S} \quad \text { : "The answer?" } \\
& \mathrm{R} \quad \text { : "Why did you say that?" } \\
& \mathrm{S} \quad \text { :"Three minus two is one. Then } \\
& \\
& \quad a \text { and } b \text { would be mixed." }
\end{aligned}
$$

S's trying to communicate with her way of thinking orally. She cannot explains well what she did, since she doesn't know well why she did the steps (Wilson, 2009). The mostly error that happened to the student is inappropriate data so that the solving problem procedure leads to the wrong answer (Munawaroh et al., 2018). It is because the students' understanding of the concept does not complete yet.

Then $\mathrm{R}$ gives her a paper included some questions on it. S's solving them on that paper. Out of 6 questions, 3 questions is true. The question above (in the previous conversation) is question number 6 . She got that number wrong answer. She is always confused when it comes to addition and subtraction but goes wrong to multiplication operation. For example, she answer question number $4, a+$ $2 b+a=2 b a a$. But when she asked why she explained that $a$ is one and add that to $2 b$. And got a new answer by $3 b$. Then for question number 4 , her answer is also wrong. Question number 5, $2 x+5 x=7 x$. She got it right and know that $x$ in $2 x$ and $5 x$ is like terms.

When it comes to multiplication and division, she got the answer right. For question number 2, $2 a \times 2 b=4 a b$ and question number $3, \frac{20 a}{2}=10 a$. She explains how she got these answers. She said that she just operating them like usual. For question number 2 , she uses multiplication and for question number 3 , she uses division.

But when it comes to the basic concept like variable and coefficient, 
she still confusing about that. Like on question number 1 , she said that there are 3 variables exists in $-9 x^{3}-$ $3 x^{3} y^{2}+12 y^{2}+6 x^{2} y^{3}-5$. And said that the coefficient from $-3 x^{3} y^{2}$ is $-3 y^{5} x$.

By providing the learning material in a fun way, it could make the students love to learn math (Yusra \& Saragih, 2016). Loving math and understanding it is not that simple. Particularly, when algebra is concerned with secondary education, the learning process is a crucial point (Vandebrouck, 2013). In algebra, the students must learn to think algebraically that involves the formation of generalization of experience with numbers and calculations, formalizing ideas using meaningful symbols, and explore the concept of pattern and function (Paridjo \& Waluya, 2017).

There are so many factors that can make the students' misunderstanding about algebra material. The teacher's uncompleted explanation could make them confusing and finally could not understand what happened to this material. It leads to misunderstanding even the definition of a variable, coefficient, and constant. In another study, there's a teacher that she or he had a lack of knowledge about the concept of the constant term (Girit \& Akyuz, 2017). This case would make even a bigger problem for both the teacher and the students if no one else explains to her or him those concepts.

Actually, students' problem when it is related to mathematical learning, is not only about the concept but also another factor. When it comes to conceptual knowledge, the teachers need to know how to teach them to the students, because misconception leads to another error like principle error, procedural error, and factual error.

\section{CONCLUSION}

This case study concludes that the students' error was the conceptual error in determining and solving of terms of algebraic forms. But actually, it is not the only problem in algebra learning. Another example is the students do not know why coefficient 1 in $a$ is not written by $1 a$ or when they confused how $a+a=2 a$ because of that problem.

Some students like $\mathrm{S}$, could not communicate their idea from one form to another form as S's did. They could not explain why did they do that because of a lack of knowledge about the basic concepts. The low communication ability students need special guidance in the learning process (Disasmitowati \& Utami, 2017). Even though the role of the teacher is really important to improve the students' ability to understand and communicate the problem, the teachers should put more attention to them.

\section{REFERENCES}

Agasi, G. R., Wahyuono, Y. D., \& Rudhito, M. A. (2017). Junior High School Students' Ability to Apply Algebra in Real-World Problems. International Journal of Indonesian Education and Teaching, 1(2), 206-215.

Andriani, P. (2015). Penalaran Aljabar dalam Pembelajaran Matematika. Jurnal Pendidikan Matematika Beta, 8(1), 1-15.

Baroody, A. J., \& Coslick, R. T. (1993). Problem Solving, Reasoning, and Communicating, K-8 Helping Children Think Mathematicaly. Merrill. 
Brown, J., Skow, K., \& the IRIS Center. (2016). Mathematics : Identifying and Addressing Student Errors.

Daud, Y., \& Ayub, A. S. (2019). Student Error Analysis in Learning Algebraic Expression: A Study in Secondary School Putrajaya. Creative Education, 10, 26152630.

https://doi.org/10.4236/ce.2019.10 12189

Disasmitowati, C. E., \& Utami, A. S. (2017). Analysis of Students' Mathematical Communication Skill for Algebraic Factorization Using Algebra Block. International Conference on Research in Education, 20(2), 7284.

Girit, D., \& Akyuz, D. (2017). Investigating Teaching Practices for Algebraic Expressions Within a Multiple Case Study. The Eurasia Proceedings of Educational \& Social Sciences (EPESS), 6, 31-37.

Julius, E., Abdullah, A. H., \& Suhairom, N. (2018). Attitude of Students towards Solving Problems in Algebra: A Review of Nigeria Secondary Schools. IOSR Journal of Research \& Method in Education, $\quad 8(1), \quad 26-31$. https://doi.org/10.9790/73880801032631

Kanbir, S., Clements, M. A. (Ken), \& Ellerton, N. F. (2018). Using Design Research and History to Tackle a Fundamental Problem with School Algebra. Springer International Publishing AG. https://doi.org/10.1007/978-3-31959204-6

Lai, C.-F. (2012). Error Analysis in Mathematics. Behavioral Research and Teaching.
Leung, F. K. S., Clarke, D., Holton, D., \& Park, K. (2014). How is Algebra Taught around the World? In F. K. S. Leung, D. Clarke, D. Holton, \& K. Park (Eds.), Algebra Teaching around The World. Sense Publisher.

Molina, M., Rodríguez-Domingo, S., Cañadas, M. C., \& Castro, E. (2017). Secondary School Students' Errors in the Translation of Algebraic Statements. International Journal of Science and Mathematics Education, 15(6), 1137-1156. https://doi.org/10.1007/s10763016-9739-5

Munawaroh, N., Rohaeti, E. E., \& Aripin, U. (2018). Analisis Kesalahan Siswa Berdasarkan Kategori Kesalahan Menurut Watson dalam Menyelesaikan Soal Komunikasi Matematis Siswa SMP. Jurnal Pembelajaran Matematika Inovatif (JPMI), 1(5), 993-1004.

NCTM. (2000). Principles and Standards for School Mathematics. NCTM. Inc.

Ncube, M. (2016). Analysis of Errors Made by Learners in Simplifying Algebraic Expressions at Grade 9 Level.

Paridjo, \& Waluya, S. B. (2017). Analysis Mathematical Communication Skills Students in The Matter Algebra Based Nctm. IOSR Journal of Mathematics, 13(I), 60-66. https://doi.org/10.9790/57281301056066

Pepin, B., Bergem, O. K., \& Klette, K. (2014). Rethinking Algebra Teaching in the Light of "Orchestration of Signs" - 
DOI: https://doi.org/10.24127/ajpm.v9i2.2687

Exploring the "Equal Sign" in a Norwegian Mathematics Classroom. In F. K. S. Leung, D. Clarke, D. Holton, \& K. Park (Eds.), Algebra Teaching around The World. Sense Publisher.

Strømskag, H. (2016). A Pattern-Based Approach to Elementary Algebra. CERME 9 - Ninth Congress of the European Society for Research in Mathematics Education.

Trisnawati, Pratiwi, R., \& Waziana, W. (2018). The Effect of Realistic Mathematics Education on Student's Mathematical Communication Ability. Malikussaleh Journal of Mathematics Learning (MJML), 1(1), 31-35. https://doi.org/10.2991/icm2e18.2018 .48

Van de Walle, J. A., Karp, K. S., \& Bay-Williams, J. M. (2016). Elementary and Middle School Mathematics: Teaching Developmentally (M. Fossel (Ed.); Ninth). Pearson Education.

Vandebrouck, F. (Ed.). (2013). Mathematics Classrooms: Students' Activities and Teachers' Practices. Sense Publishers.

Wilson, B. (2009). Mathematical Communication through Written and Oral Expression.

Yusra, D. A., \& Saragih, S. (2016). The Profile of Communication Mathematics and Students' Motivation by Joyful Learningbased Learning Context Malay Culture. British Journal of Education, Society, \& Behavioral Science, 15(4), 1-16. https://doi.org/10.9734/BJESBS/20 $16 / 25521$ 